\title{
Phytochemical constituents and antimicrobial evaluation of ethanolic extracts from Pleurotus spp. cultivated on substrate fortified with selenium
}

\author{
Fasoranti $\mathrm{OF}^{1^{*}}$, Ogidi $\mathrm{CO}^{1,2}$ and Oyetayo $\mathrm{VO}^{1}$ \\ ${ }^{1}$ Department of Microbiology, The Federal University of Technology, PMB 704, Ondo State, Nigeria. \\ ${ }^{2}$ Biotechnology Unit, Department of Biological Sciences, Kings University, PMB 555, Odeomu, Nigeria
}

Fasoranti OF, Ogidi CO and Oyetayo VO 2018 -Phytochemical constituents and antimicrobial evaluation of ethanolic extracts from Pleurotus spp. cultivated on substrate fortified with selenium. Microbial Biosystems 3(2), 29-39.

\begin{abstract}
Edible mushrooms have the ability to bio-accumulate minerals from the growth medium into the fruiting body. Selenium (Se) is an example of minerals that can be easily absorbed by mushroom. This study investigated the phytochemical constituents and antimicrobial properties of Pleurotus spp. fortified with selenium. Pleurotus spp. (fortified with selenium and nonfortified with selenium) were cultivated on corn cobs using standard procedures. The yield, biological efficiency, selenium absorption level, phytochemical constituents and antimicrobial properties were determined using standard methods. Non-fortified Pleurotus pulmonarius recorded the highest yield and biological efficiency, while fortified Pleurotus ostreatus had the lowest yields and biological efficiency. There was no significant difference $(\mathrm{P}<0.05)$ in the selenium concentration absorbed in Pleurotus ostreatus $(51.79 \mu \mathrm{g} / \mathrm{g})$ and Pleurotus pulmonarius $(59.29 \mu \mathrm{g} / \mathrm{g})$ but no selenium was detected in the non-fortified samples. The presence of 5 phytochemicals viz; saponins, alkaloids, phenols, tannins and flavonoids were detected in cultivated mushrooms. Saponin was highest $(7.08 \mathrm{mg} / \mathrm{g})$ in non-fortified Pleurotus pulmonarius while tannin was the least with the value of $0.02 \mathrm{mg} / \mathrm{g}$ in fortified Pleurotus ostreatus. The ethanolic extracts of Pleurotus spp. inhibited the growth of Gram positive and negative bacteria with Pseudomonas aeruginosabeen the most susceptible $(25.00 \mathrm{~mm})$. The ethanolic extracts of fortified Pleurotus spp. inhibited Aspergillus flavus, Candida albicans and Candida parapsilosis. The non-fortified extracts however, had no inhibitory effects on the tested fungi. Based on the findings of this study, it can be concluded that Se-fortification increased the antibacterial activities of Pleurotus spp. These results therefore, suggest that Se-enriched mushrooms can be used as potential source of dietary supplements and nutraceuticals. Fortification of Pleurotus spp. with essential metals should be encouraged as this can improve its health promoting property.
\end{abstract}

Key words -Antimicrobial, phytochemical, Pleurotus species, selenium.

\section{Introduction}

Pleurotus spp. is among the edible mushrooms consumed in Nigeria. It is used as spice in vegetable soups and also fried to serve as meat (Iwalokun et al. 2007). Taxa of the Pleurotus genus have an important place among the commercially employed basidiomycetes because they

Submitted 14 November 2018, Accepted 29 December 2018, Published online 31 December 2018 permits unrestricted use, distribution, and reproduction in any medium, provided the original author and source are credited. 
have gastronomic, nutritional and medicinal properties. They can be easily cultivated on a wide range of substrates (Pauliuc and Botău 2013). Apart from their nutritional potentials, mushrooms are also sources of bioactive substances that possess health benefits (Oyetayo et al. 2009). These metabolites have been used as antimicrobials with fewer side effects and are a prolific resource for drugs because of their antitumor, antibacterial, antifungal and hypercholesterolemia activities (Selima 2012). Phenolic and tannin constituents of $P$. ostreatus may also elicit antibacterial activity as found in many medicinal plants with mechanisms of action characterized by cell memberane lysis, inhibition of protein synthesis, proteolytic enzymes and microbial adhensins (Filipic et al. 2002).

The yield and chemical composition of mushrooms depend on the substrate used for their cultivation (Shashirekha et al. 2005). The yield and chemical composition can be enhanced by adding micronutrients such as Selenium (Se) to the substrate (Zhao et al. 2004). Se is an essential micronutrient required for the biosynthesis of biologically significant selenoenzymes and selenoproteins. Its optimal intake could potentially prevent various types of cancer and diseases like diabetes, age-related immunosuppression and even problems related to fertility (Sharma et al. 2018). Se deficiency often occur in patients with severely compromised intestinal function, those undergoing parenteral nutrition, those who have had gastro intestinal bypass surgery persons of advanced age and HIV patients (Ravagla et al. 2000). Se deficiency leads to infertility in men and women, muscle weakness, fatigue, mental fog, hair loss and weakened immune system(Olsen 2018). Life threatening diseases such as cancer, cardiovascular disease, susceptibility to viral infections, asthma, Kashan disease, thyroid dysfunction and osteoarthritis can also occur as a result of deficiency of Se in human blood (Papp et al. 2010). Considering the importance of Se in human, it can be incorporated into human diet through the process of biofortification. Due to mushrooms' ability to absorb inorganic Se forms and convert them to bioactive cell compounds, they could be used as food and dietary supplements and this represent an effective way to improve health (Milovanović et al. 2013).

Keeping in view the health benefits of mushrooms and selenium, this study was conducted to determine the effects of selenium-biofortification on the phytochemical constituents and antimicrobial activities of twoPleurotus spp. (P. ostreatus and P. pulmonarius)

\section{Materials and Methods \\ Collection of Corn Cobs}

The corn cobs used as substrates for this research work were procured at the King's market, Akure, Ondo State.

\section{Source of Pleurotus spp. spawn}

Spawns of Pleurotus ostreatus and Pleurotus pulmonarius were obtained from Federal Institute of Industrial Research (FIRO), Oshodi Lagos, Nigeria. The spawns were taken to the Department of Microbiology Federal University of Technology, Akure for confirmation.

\section{Test microorganisms}

All tested bacteria and fungi were obtained from the stock cultures maintained in the Microbiology Laboratory, Federal Medical Centre (FMC), Owo, Ondo State. The cultures were maintained on slants of Nutrient Agar and Potato Dextrose Agar and kept at $4{ }^{\circ} \mathrm{C}$ until when required for use. A total of 11 bacteria and 4 fungi were used. They include: Pseudomonas aeruginosa, Staphylococcus aureus, Klebsiella pneumoniae, Proteus mirabilis, Escherichia coli, Bacillus cereus, Enterobacter aerogenes, Salmonella dysenteriae, Seratia marcescens, Streptococcus viridans, Streptococcus oralis, Aspergillus flavus, Aspergillus niger, Candida albicans and Candida parapsilosis. 


\section{Substrate preparation}

Corn cobs were sundried and milled into smaller pieces using mortar and pestle and further pulverized into fine powdered using commercial milling machine.The substrate was moistened with water to a concentration of $60 \%$. Approximately $1000 \mathrm{~g}$ of the substrate was packed into polypropylene bags and sealed with paper with the aid of polyvinyl rings. The bags were then autoclaved for 2 hours at $121^{\circ} \mathrm{C}$

\section{Mushroom preparation}

The substrates were allowed to cool down and then inoculated with $30 \mathrm{~g}$ of Pleurotus spawn. Sodium selenite $\left(\mathrm{Na}_{2} \mathrm{SeO}_{3}\right)$ of $50 \mathrm{mg} / \mathrm{Kg}$ was injected into each package. A control treatment with no sodium selenium was also prepared. The bags were then kept in spawn room with $75 \%$ relative humidity until formation of primordia. The bags were then uncapped and transferred to the fruiting room to allow the normal development of the fruit bodies. The bags were kept in bed position on the rack.

\section{Harvesting of basidiomata}

As soon as the fruiting bodies developed and attained their full size, they were harvested by twisting to uproot from the base. The harvesting was done in three flushes of 10 days intervals.

\section{Calculation of total yield}

Mean fresh weight of the flushes of each bag was calculated for total yield. The whole cluster of fruiting bodies was considered for biological yield measurement. Biological efficiency (B.E) was calculated according to Ahmed et al. (2013) as follows :

$$
\mathrm{B} . \mathrm{E}=\frac{\text { grams of fresh weight of mushroom }}{\text { dry weight of substrate }} \quad \mathrm{X} 100
$$

\section{Preparation of mushroom extracts}

The mushroom samples were cut into small pieces and air dried. The dried sample was ground into fine powder. Mushroom (250g) was soaked in $1000 \mathrm{ml}$ of ethanol and kept for three days with occasional shaking. Each portion was then filtered using Whatman filter paper No 1. The filtrates were evaporated to dryness and the extracts (residues) were stored at $4{ }^{\circ} \mathrm{C}$ in a sterile container for further use.

\section{Determination of Selenium Concentration in Cultivated Pleurotus spp.}

The digestion of the dried mushroom fruit bodies was carriedout by mixing the $0.1 \mathrm{~g}$ of sample with $8 \mathrm{ml}$ of65 \% $\mathrm{HNO}_{3}$, suprapur (Sigma Aldrich, St. Louis, MO, USA). The prepared sample was then digested under a closed-vessel microwave digester (Anton Paar India Pvt. Ltd., India) at a high temperature $\left(180^{\circ} \mathrm{C}\right)$ with maximum pressure increase rate $(0.5 \mathrm{bar} / \mathrm{sec})$ and power $(1200 \mathrm{~W})$ for 30 minutes. After digestion, the solution obtained was filtered using a Millipore $45 \mathrm{~mm}$ filters (qualitative filter papers, Grade 595: 4-7 mm, Whatman, UK) and was made up to a final volume of $50 \mathrm{ml}$ using deionised water (Milli-Q Advanced A10 Water Purification Systems, Merck, Darmstadt, Germany). The total Se content was determined using an inductively coupled plasma mass spectrometry (Agilent ICP-MS 7900, Agilent Technologies, Santa Clara, CA, USA). The commercial Se standard (Sigma Aldrich) in $1 \mathrm{~g} / \mathrm{L}$ concentration was used as the appropriate diluted standard for preparation of the calibration curve. The linearity of the calibration curve was 0.9996 ; the detection limit for the samples was $0.0007 \mathrm{mg} / \mathrm{L}$. The method for determination of the Se was validated using the pure Se standards (Rathore et al. 2018). 


\section{Phytochemical analysis of cultivatedPleurotus spp.}

Phytochemicals screenings were carried out on the powdered samples to identify their major constituents such as alkaloids, saponins, tannins, flavonoid, steroid, phytate, phenols and oxalate using standard qualitative methods as described by Parihar et al. (2015).

\section{Antimicrobial Analysis of Pleurotus spp.}

Antibacterial activity of the pleurotus spp. extract was tested using agar well diffusion method (Balakumar et al. 2011) with modification. Petri dishes with nutrient agar were inoculated with a $100 \mu \mathrm{l}$ suspension of each bacterial culture. Wells were made on the agar surface with $6 \mathrm{~mm}$ cork borer. The bacteria seeded plates were placed in the refrigerator for 8 hours at $4{ }^{\circ} \mathrm{C}$. Extracts was reconstituted in 3.0\% dimethyl sulfoxide (DMSO) and filtered through $0.22 \mu \mathrm{m}$ before introduced into the well. Chloramphinecol was used as standard antibiotics (control) for bacteria while ketoconazole was used as control for fungi. The plates were then incubated at $37 \pm 2{ }^{\circ} \mathrm{C}$ for $24 \mathrm{~h}$ and $26{ }^{\circ} \mathrm{C}$ for 48 to $72 \mathrm{~h}$ for bacteria and fungi respectively. The plates were observed for the inhibited zones around the wells and measured in millimeter. The minimum inhibition concentration of each extracts were determined by ranging the concentration of the extracts from 10 to $200 \mu \mathrm{g}$. Antifungal activity of ethanolic extract of Pleurotus spp. was determined by the agar well diffusion modified method of Oyetayo et al. (2009).

\section{Statistical Analysis}

All the treatments were carried out in triplicates and thedata obtained were analyzed using analysis of variance (ANOVA). Means were separated using Duncan's New Multiple Range Test at 95\% confidence level using Statistical Packages for the Social Sciences (SPSS) version 17.0.

\section{Results}

Table 1 shows the total yield and biological efficiency of the cultivated Pleurotus spp. The Pleurotus spp. were harvested in three flushes. Non-fortified Pleurotus spp. (PPN) at the second flush had the highest yield $(196.00 \mathrm{~g})$ while selenium fortified Pleurotus ostreatus (POS) had the lowest yield at the third flush $(95.00 \mathrm{~g})$. Non-fortified Pleurotus pulmonarius (PPN) had the highest biological efficiency $(177.73 \%$ ) while fortified Pleurotusostreatus (POS) had the lowest biological efficiency (113.73\%).

Table 1 Yield and biological efficiency (B.E) of cultivated Pleurotus spp.

\begin{tabular}{rrrrr}
\hline Samples & $1^{\text {st }}$ flush $(\mathrm{g})$ & $2^{\text {nd }}$ flush $(\mathrm{g})$ & $3^{\text {rd }}$ flush $(\mathrm{g})$ & B.E $(\%)$ \\
\hline PON & $161.00 \pm 2.00^{\mathrm{c}}$ & $176.50 \pm 2.50^{\mathrm{b}}$ & $120 \pm 10.00^{\mathrm{b}}$ & $152.50^{\mathrm{b}}$ \\
POS & $121.20 \pm 7.50^{\mathrm{a}}$ & $125.00 \pm 15.00^{\mathrm{a}}$ & $95.00 \pm 10.00^{\mathrm{a}}$ & $113.73^{\mathrm{a}}$ \\
PPS & $137.00 \pm 4.00^{\mathrm{b}}$ & $141.20 \pm 2.50^{\mathrm{a}}$ & $121.20 \pm 7.50^{\mathrm{b}}$ & $133.13^{\mathrm{a}}$ \\
PPN & $190.00 \pm 5.00^{\mathrm{d}}$ & $196.00 \pm 7.50^{\mathrm{b}}$ & $147.20 \pm 5.00^{\mathrm{c}}$ & $177.73^{\mathrm{c}}$ \\
\hline
\end{tabular}

Values are means of triplicates \pm SD. Values carrying the same alphabets in the same column are not significantly different at ( $p>0.05)$. Values are means of triplicates \pm SD. Where : PPN= Pleurotus pulmonarius (non-fortified with selenium), $\mathrm{PPS}=P$. pulmonarius (fortified with selenium), $\mathrm{PON}=P$. ostreatus (non-fortified with selenium) and $\mathrm{POS}=P$. ostreatus (fortified with selenium).

Table 2 shows the concentration of selenium (Se) in the cultivated Pleurotus spp. Nonfortified Pleurotus ostreatus (PON) and non-fortified Pleurotus pulmonarius (PPN) had no selenium. Fortified Pleurotus ostreatus (POS) and Pleurotus pulmonarius (PPS) recorded a Se concentration of $51.79 \mu \mathrm{g} / \mathrm{g}$ and $59.29 \mu \mathrm{g} / \mathrm{g}$ respectively and there was no significant differences $(\mathrm{P}<0.05)$ in their Seconcentration. 
Table 2 Selenium content of Pleurotus spp. after fortification $(\mu \mathrm{g} / \mathrm{g})$.

\begin{tabular}{ll}
\hline Sample & Concentration \\
\hline PON & $0.00 \pm 0.00^{\mathrm{a}}$ \\
POS & $51.79 \pm 2.60^{\mathrm{b}}$ \\
PPS & $59.29 \pm 1.52^{\mathrm{b}}$ \\
PPN & $0.00 \pm 0.00^{\mathrm{a}}$ \\
\hline
\end{tabular}

Values are means of triplicates \pm SD. Values carrying the same alphabets in the same column are not significantly different at $(\mathrm{p}>0.05)$. Values are means of triplicates \pm SD. Where : PPN= Pleurotus pulmonarius (non-fortified with selenium), $\mathrm{PPS}=P$. pulmonarius (fortified with selenium), $\mathrm{PON}=P$. ostreatus (non-fortified with selenium) and $\mathrm{POS}=P$. ostreatus (fortified with selenium).

Table 3 shows the quantitative phytochemicals of the cultivated Pleurotus spp. Saponins had the highest value in all cultivated Pleurotus spp.: fortified Pleurotus ostreatus $(4.29 \mathrm{mg} / \mathrm{g})$, fortified Pleurotus pulmonarius $(5.34 \mathrm{mg} / \mathrm{g})$, non-fortified Pleurotus pulmonarius $(5.58 \mathrm{mg} / \mathrm{g})$, and non-fortified Pleurotus ostreatus $(7.08 \mathrm{mg} / \mathrm{g})$ while tanins had the least value in all cultivated Pleurotus spp.: fortified Pleurotus ostreatus $(0.02 \mathrm{mg} / \mathrm{g})$, Non-fortified Pleurotus ostreatus $(0.03 \mathrm{mg} / \mathrm{g})$, non-fortified Pleurotus pulmonarius $(0.03 \mathrm{mg} / \mathrm{g})$ and fortified Pleurotus pulmonarius $(0.03 \mathrm{mg} / \mathrm{g})$. Alkaloids, phenols and flavonoids ranged from $1.38-4.37 \mathrm{mg} / \mathrm{g}, 0.08$ $0.39 \mathrm{mg} / \mathrm{g}$ and $0.26-1.23 \mathrm{mg} / \mathrm{g}$ respectively.

Table 3Phytochemical composition (mg/g) of Pleurotus spp. fortified with selenium.

\begin{tabular}{lllll}
\hline Composition & PPN & PPS & POS & PON \\
\hline Alkaloids & $4.37 \pm 0.13^{\mathrm{d}}$ & $1.23 \pm 0.07^{\mathrm{b}}$ & $3.40 \pm 0.12^{\mathrm{c}}$ & $1.38 \pm 0.06^{\mathrm{a}}$ \\
Phenols & $0.23 \pm 0.13^{\mathrm{a}}$ & $0.23 \pm 0.13^{\mathrm{a}}$ & $0.08 \pm 0.01^{\mathrm{a}}$ & $0.39 \pm 0.51^{\mathrm{a}}$ \\
Tannins & $0.03 \pm 0.01^{\mathrm{a}}$ & $0.03 \pm 0.00^{\mathrm{a}}$ & $0.02 \pm 0.00^{\mathrm{a}}$ & $0.03 \pm 0.01^{\mathrm{a}}$ \\
Saponins & $5.58 \pm 0.13^{\mathrm{c}}$ & $5.34 \pm 0.02^{\mathrm{b}}$ & $4.29 \pm 0.06^{\mathrm{a}}$ & $7.08 \pm 0.08^{\mathrm{d}}$ \\
Flavonoids & $1.23 \pm 0.07^{\mathrm{b}}$ & $0.74 \pm 0.58^{\mathrm{b}}$ & $0.26 \pm 0.04^{\mathrm{a}}$ & $0.44 \pm 0.02^{\mathrm{a}}$ \\
\hline
\end{tabular}

Values are means of triplicates \pm SD. Values carrying the same alphabets in the same column are not significantly different at ( $p>0.05)$. Values are means of triplicates \pm SD. Where : PPN= Pleurotus pulmonarius (non-fortified with selenium), $\mathrm{PPS}=P$. pulmonarius (fortified with selenium), $\mathrm{PON}=P$. ostreatus (non-fortified with selenium) and $\mathrm{POS}=P$. ostreatus $($ fortified with selenium).

Table 4 shows the in_vitro antibacterial activities of ethanolic extracts of the cultivated Pleurotus spp. against eleven (11) bacteria. All extracts exhibited antibacterial activities against all the tested bacteria. Extracts from fortified Pleurotus pulmonarius (PPS) had the highest zones of inhibition (21.00-25.30 mm) against tested organisms. The zones of inhibition displayed by PPS (21.00-25.30 mm) compared favourably with the conventional antibiotic; chloramphenicol (12.70-25.00 mm). Extracts from non-fortified Pleurotus ostreatus (PON) had the lowest zones of inhibition (9.00-18.00 mm).

Table 5 shows the minimum inhibitory concentration of ethanolic extracts of the cultivated Pleurotus. The minimum inhibitory concentration displayed by extracts of fortified Pleurotus species against all test bacteria ranged from $50 \mu \mathrm{g} / \mathrm{g}$ to $150 \mu \mathrm{g} / \mathrm{g}$ while the minimum inhibitory concentration displayed by extracts of non-fortified Pleurotus species ranged from 50$200 \mu \mathrm{g} / \mathrm{g}$ against all test bacteria.

Table 6 shows the antifungal activities of ethanolic extracts of cultivated Pleurotus spp. Ethanolic extracts of non-fortified Pleurotus spp. showed no zones of inhibition against all tested fungi at a concentration of $200 \mu \mathrm{g} / \mathrm{g}$. Extracts of fortified Pleurotus spp. however displayed zones of inhibitions against Aspergillus flavus (13.00 mm), Candida albicans $(11.00-13.00 \mathrm{~mm})$ and Candida parapsilosis $(13.00 \mathrm{~mm})$ at a concentration of $200 \mu \mathrm{g} / \mathrm{g}$. 
Table 4 Zones of inhibition(mm) displayed by ethanolic extracts of cultivated Pleurotus spp. against bacteria at $200 \mu \mathrm{g} / \mathrm{g}$.

\begin{tabular}{llllll}
\hline Isolates & PON & PPN & PPS & POS & CHL \\
\hline Pseudomonas aeruginosa & $15.30 \pm 1.54^{\mathrm{a}}$ & $14.00 \pm 1.00^{\mathrm{a}}$ & $25.00 \pm 1.00^{\mathrm{c}}$ & $21.70 \pm 1.15^{\mathrm{b}}$ & $23.30 \pm 0.58^{\mathrm{b}}$ \\
Staphylococcus aureus & $15.70 \pm 0.58^{\mathrm{a}}$ & $13.70 \pm 0.58^{\mathrm{a}}$ & $21.30 \pm 2.89^{\mathrm{c}}$ & $16.70 \pm 1.52^{\mathrm{b}}$ & $24.00 \pm 1.00^{\mathrm{c}}$ \\
Klebsiella pneumoniae & $15.30 \pm 0.58^{\mathrm{a}}$ & $15.00 \pm 1.73^{\mathrm{a}}$ & $21.30 \pm 2.89^{\mathrm{c}}$ & $17.70 \pm 1.15 \mathrm{a}$ & $21.70 \pm 0.58^{\mathrm{b}}$ \\
Proteus mirabalis & $13.00 \pm 1.00^{\mathrm{a}}$ & $15.00 \pm 2.00^{\mathrm{a}}$ & $22.30 \pm 5.00^{\mathrm{b}}$ & $22.00 \pm 1.00^{\mathrm{b}}$ & $12.30 \pm 1.15^{\mathrm{a}}$ \\
Escherichia coli & $14.00 \pm 1.00^{\mathrm{a}}$ & $15.70 \pm 3.06^{\mathrm{a}}$ & $24.00 \pm 1.73^{\mathrm{c}}$ & $19.70 \pm 2.08^{\mathrm{b}}$ & $24.00 \pm 1.73^{\mathrm{c}}$ \\
Bacillus cereus & $9.00 \pm 2.00^{\mathrm{a}}$ & $14.30 \pm 3.21^{\mathrm{b}}$ & $23.70 \pm 2.08^{\mathrm{c}}$ & $17.00 \pm 2.00^{\mathrm{b}}$ & $23.70 \pm 1.15^{\mathrm{c}}$ \\
Enterococcus aerogenes & $10.00 \pm 1.00^{\mathrm{a}}$ & $16.70 \pm 3.51^{\mathrm{b}}$ & $24.00 \pm 1.00^{\mathrm{d}}$ & $19.30 \pm 2.08^{\mathrm{c}}$ & $21.30 \pm 0.58^{\mathrm{c}}$ \\
Streptococcus viridans & $13.00 \pm 1.00^{\mathrm{a}}$ & $11.30 \pm 1.53^{\mathrm{a}}$ & $21.00 \pm 2.00^{\mathrm{b}}$ & $20.00 \pm 1.73^{\mathrm{b}}$ & $12.70 \pm 1.15^{\mathrm{a}}$ \\
Salmonella dysenteriae & $11.30 \pm 1.52^{\mathrm{a}}$ & $12.30 \pm 0.58^{\mathrm{a}}$ & $23.70 \pm 2.08^{\mathrm{c}}$ & $17.30 \pm 1.53^{\mathrm{b}}$ & $24.00 \pm 1.00^{\mathrm{c}}$ \\
Streptococcus oralis & $18.00 \pm 2.00^{\mathrm{a}}$ & $14.70 \pm 2.08^{\mathrm{a}}$ & $25.30 \pm 1.53^{\mathrm{b}}$ & $19.00 \pm 2.00^{\mathrm{a}}$ & $25.00 \pm 1.73^{\mathrm{b}}$ \\
Seratia marcescens & $14.70 \pm 2.53^{\mathrm{a}}$ & $15.00 \pm 1.00^{\mathrm{a}}$ & $24.30 \pm 1.00^{\mathrm{c}}$ & $18.30 \pm 1.15^{\mathrm{b}}$ & $22.30 \pm 2.52^{\mathrm{c}}$ \\
\hline Val
\end{tabular}

Values are means of triplicates \pm SD. Values carrying the same alphabets in the same row are not significantly different at $(\mathrm{p}>0.05)$. Where $\mathrm{PPN}=$ Pleurotus pulmonarius (non-fortified with selenium), PPS=P. pulmonarius (fortified with selenium), $\mathrm{PON}=P$. ostreatus (non-fortified with selenium), $\mathrm{POS}=P$. ostreatus (fortified with selenium), CHL: Chloramphinecol.

Table 5 Minimum inhibitory concentration $(\mu \mathrm{g} / \mathrm{g})$ of ethanolic extracts of Pleurotus spp. against test bacteria.

\begin{tabular}{lllll}
\hline Isolates & PPN & PPS & POS & PON \\
\hline Pseudomonas aeruginosa & 100 & 50 & 100 & 100 \\
Staphylococcus aureus & 100 & 50 & 150 & 150 \\
Klebsiella pneumoniae & 100 & 50 & 150 & 150 \\
Proteus mirabalis & 150 & 50 & 150 & 150 \\
Escherichia coli & 150 & 50 & 50 & 100 \\
Bacillus cereus & 150 & 50 & 150 & 200 \\
Enterobacter aerogenes & 100 & 50 & 50 & 250 \\
Streptococcus viridans & 150 & 50 & 100 & 150 \\
Salmonella dysenteriae & 100 & 50 & 100 & 200 \\
Streptococcus oralis & 100 & 50 & 150 & 150 \\
Seretia. Marcescens & 150 & 50 & 150 & 100
\end{tabular}

Where PPN $=$ Pleurotus pulmonarius (non-fortified with selenium), PPS $=P$. pulmonarius (fortified with selenium), $\mathrm{PON}=P$. ostreatus (non-fortified with selenium) and POS $=P$. ostreatus (fortified with selenium).

Table 6 Zones of inhibition $(\mathrm{mm})$ displayed by ethanolic extracts of cultivated Pleurotus spp. against fungi at $200 \mu \mathrm{g} / \mathrm{g}$.

\begin{tabular}{llllll}
\hline Isolates & PON & PPN & PPS & POS & KCZ \\
\hline Aspergillus flavus & $0.00 \pm 0.00^{\mathrm{a}}$ & $0.00 \pm 0.00^{\mathrm{a}}$ & $13.00 \pm 1.00^{\mathrm{b}}$ & $13.00 \pm 1.00^{\mathrm{b}}$ & $23.30 \pm 0.58^{\mathrm{c}}$ \\
Aspergillus niger & $0.00 \pm 0.00^{\mathrm{a}}$ & $0.00 \pm 0.00^{\mathrm{a}}$ & $0.00 \pm 0.00^{\mathrm{a}}$ & $0.00 \pm 0.00^{\mathrm{a}}$ & $24.00 \pm 1.73^{\mathrm{b}}$ \\
Candida albicans & $0.00 \pm 0.00^{\mathrm{a}}$ & $0.00 \pm 0.00^{\mathrm{a}}$ & $11.00 \pm 1.00^{\mathrm{b}}$ & $13.00 \pm 1.00^{\mathrm{b}}$ & $24.00 \pm 1.00^{\mathrm{c}}$ \\
Candida parapsilosis & $0.00 \pm 0.00^{\mathrm{a}}$ & $0.00 \pm 0.00^{\mathrm{a}}$ & $13.00 \pm 1.00^{\mathrm{b}}$ & $0.00 \pm 0.00^{\mathrm{a}}$ & $25.00 \pm 1.73^{\mathrm{c}}$ \\
\hline
\end{tabular}

Values are means of triplicates \pm SD. Values carrying the same alphabets in the same row are notsignificantly different at $(\mathrm{p}>0.05)$. Where PPN =Pleurotus pulmonarius (non-fortified with selenium), PPS $=$ P. pulmonarius (fortified with selenium), PON $=P$. ostreatus (non-fortified with selenium), POS $=P$. ostreatus (fortified with selenium) and $\mathrm{KCZ}=$ Ketoconazole. 


\section{Discussion}

Edible fungi especially Pleurotus spp. have been used as dietary supplements when there are deficiencies of certain constituents in natural foods. This is because of their ability to absorb micro and macro nutrients from the substrates used for their cultivation (Ling et al. 2015). The enrichment of foods with micronutrients such as Selenium (Se) is very desirable (Finley 2006). This enrichment presents the opportunity to use bio-fortified foods as natural sources of antimicrobials and antioxidants. This present study emphasizes on the effect of Se biofortification on the phytochemical constituents and antimicrobial activities of Pleurotus spp.

The results obtained from the yield and biological efficiency (BE) of Pleurotus spp. show that the second flush produced the highest yield of mushrooms. The addition of Se to the substrates however caused a reduced yield. This result correlates with the observations of Da Silva et al. (2012) and Ogidi et al. (2017). The highest BE (177.73\%) was obtained from nonfortified Pleurotus pulmonarius while fortified Pleurotus ostreatus (POS) had the least BE. These results confirm that mushroom yield and BE varies according to the substrates used (Dias et al. 2003, Curvetto et al. 2002).Se, though important to human health can become poisonous if ingested in high quantity (Hartikainen 2005). The recommended dose for an adult (male or female) is $55-65 \mu \mathrm{g} /$ day.

Selenium ( $\mathrm{Se}$ ) has been found to be part of the biomass of Pleurotus spp. and also found to be associated with the membrane and cell wall (Munoz et al. 2006). It is recognized as an essential micronutrient for humans and animals and has an important role in biological functions that is mediated primarily by selenoproteins. Pleurotus spp. cultivated with Sodium selenite were observed to possess Se while the one not cultivated with Sodium selenite recorded no trace of Se. There was no significant difference $(\mathrm{P}<0.05)$ in the Se- level of both fortified P. ostreatus and $\mathrm{P}$. pulmonarius. This shows the high capability of these mushrooms to absorb inorganic Se and accumulate it into the fruit body of the mushroom.

Edible mushrooms display variable concentrations of Se depending on the species, compost and growth substrate conditions, such as the nutrient content and availability (Maseko et al. 2013). The results obtained from this present study $(51.79$ and $59.39 \mu \mathrm{g} / \mathrm{g})$ conforms with Da Silva et al. (2012) who reported that the level of Se found in P. ostreatus cultivated on substrate supplemented with $3.2 \mathrm{mg} / \mathrm{kg}$ of sodium selenite was $57.6 \mathrm{mg} / \mathrm{g}$. The extent of accumulation in this study was notably higher than the Se concentrations of 4.6 and 9.3 $\mathrm{mg} / \mathrm{greported}$ for $P$. eryngii cultivated on substrates supplemented with 5.0 and $10.0 \mathrm{mg} / \mathrm{kgof}$ sodium selenite, respectively (Estrada et al. 2009). The differences in these results may in part be explained by different methods used in the extraction and quantification of the selenium and also by the oxidative degradation of the se-lenocompounds (Amoako et al. 2009). The cultivation process of the fungus, the concentration and form of Se added during enrichment and the physiology of the fungus all influence the forms of Se absorption and also the capability for biotransformation (Da Silva et al. 2012). The mechanisms for the Se uptake by fruiting bodies have been reported to be due to the methylation of $\mathrm{Na}_{2} \mathrm{SeO}_{3}$ to seleno compounds viz., methylselonol, dimethylselenide, and trimethylselenonium (Rathore et al. 2018). This approach of incorporating element could serve as another nutritional source for meeting the daily dietary recommended allowances for Se (Rathore et al. 2018).

Phytochemical analyses conducted on the Selenium enriched Pleurotus spp revealed the presence of alkaloids, phenol, tannins, saponins and flavonoid. It is known that Saponins inhibit $\mathrm{Na}^{+}$efflux by blockage of the influx of concentration in the cells, activating a $\mathrm{Na}^{+}-\mathrm{Ca}^{2+}$ antiporter in cardiac muscles. The increase in $\mathrm{Ca}^{2+}$ influx through this antiporter strengthens the contraction of heart muscles (Edeoga and Enata 2001). Omojate et al. (2014) advocated that the consumption of tannin containing beverages especially green teas and red wine, can prevent or 
cure a variety of illness. Karou et al. (2011) also stated that many physiological activities such as stimulation of phygocytic cells and wide range of anti-infective actions have been attributed to tannins because of its molecular actions of forming complexes with proteins. Tannins were able to inhibit the growth of insect and disrupt the digestive activities in ruminant animals (Karou et al. 2011). Tanins have been reported to be responsible for the ability of plant to inactivate microbial adhesions, enzymes and cell envelope transport proteins (Omojate et al. 2014).

Phenolsmay also elicit antibacterial activity as found in many medicinal plants with mechanisms of action characterized by cell memberane lysis, inhibition of protein synthesis, proteolytic enzymes and microbial adhensins (Cowan 1999). Various researchers have earlier defined role of selenium in inducing antioxidant capacity by facilitating increase in the amounts of tocopherol and phenolic compounds in plants (Xie et al. 2003). The valuable pharmaceutical properties of mushroom may also be attributed to the presence of alkaloids which has been reported to have a stimulating effect, act as topical anaesthetic in ophthalmology, powerful pain reliever, antipuretic action among other uses (Edeoga et al. 2001). The presence of flavonoids in Pleurotus spp. may help provide protection against oxidative stress induced diseases by contributing along with other antioxidant, vitamins, and enzyme to the total antioxidative defense system of the human body.

The saponin, alkaloid, phenols, flavonoids and tannin contents differed from one species to another. This demonstrates the fact that, every species has its own unique mechanisms in the synthesis of these phytochemicals. Pleurotus spp. may be used as potential sources of phytochemicals and for designing drugs that can prove to be of keen interest in the treatment and prevention of diseases like cancer, tumor and heart diseases (Ashok and Shabudeen 2015).

Mushrooms have been appreciated as sources of food nutrients and especially used for medicinal purposes in the orients for centuries (Lindequist et al. 2005). Antibiotics provide the main basis for the therapy of bacterial infections. However, the high genetic variability of bacteria enables them to rapidly evade the action of antibiotics by developing antibiotic resistance (Nehra et al. 2012).

Ethanolic extract of selenium enriched Pleurotus species was found to exhibit good antibacterial effect against the test bacteria used in this study (Table 4). The extracts inhibitedboth Gram positive and negative bacteria. Thissuggested that Se fortified $P$. specieshas a broad-spectrum antibacterial activity. However, Selenium enriched Pleurotus species were more active against the test bacteria than the non-selenium fortified P. species. The maximum antibacterial effect of aqueous extract of Se enriched Pleurotus species was found against Streptococcusoralis $(25.30 \mathrm{~mm})$, Pseudomonas aeruginosa $(25.00 \mathrm{~mm})$ and minimum against Streptococcus viridians $(21.00 \mathrm{~mm})$. This is more or less similar with the results of Akyuz and Kirbag (2009) who reported that methanolic extract of Pleurotus species showed activity against Gram positive and negative bacteria at different concentrations. The resultis also similar to Iwalokun et al. (2007) who reported that macrofungus extracted with petroleum ether and acetone, inhibited Gram positive and Gram negative bacterial tested in vitro. Similarly, organic extracts (methanol and chloroform) obtained from P.ostreatus has earlier been reported to be effective against Gram-positive bacteria (Karaman et al. 2010). The mechanism of the active compounds is still to be studied; nevertheless, membrane disruption could be suggested as one of the likely mechanisms of action of the compounds belonging to the terpenoids. Based on the results of this study, it can be concluded that Se enriched Pleurotus spp. possess a broadspectrum antibacterial activity. Moreover, fortification of $P$. spp. further enhanced its antibacterial potency. The Se-fortified Pleurotus spp. had mild inhibitory effects against Candida albicans, Aspergillus flavus and Candida parapsilosis. The non-fortified Pleurotus spp. were however not active against fungi. Drugs derived from macrofungi are effective, readily available, less expensive and rarely have side effects (Parihar et al. 2015). 
Conclusively, Se-fortification in Pleurotus spp. increased the antimicrobial activities of Pleurotus spp. These results therefore suggest that Se-enriched mushrooms can be used as potential source of dietary supplements and nutraceuticals.

\section{Conflict of Interest}

The authors do not have any conflicts of interest.

\section{References}

Ahmed M., Abdullah N., Ahmed K. and Bhuyan, B. 2013. Yield and nutritional composition of oyster mushroom strains newly introduced in Bangladesh. Pesq. Agropec. Bras., 2(2):197-202.

Akyuz M. and Kirbag S. 2009. Antimicrobial activity of Pleurotus eryngii var. ferulae grown on various agro-wastes. EurAsia. J. BiolSci., 3:58-63

Amoako P.O., Uden P.C. and Tyson J.F. 2009. Speciation of selenium dietary supplements; formation of S- (methylseleno) cysteine and other selenium compounds. Anal. Chim. Acta., 652(1-2): 315-323.

Ashok A. and Shabudeen P.S.S. 2014. Phytochemical qualitative analysis and immunomodulator activity of Agaricus bisporous ethanol extract by carbon clearance technique. Biochem. Pharmacol., 4: 168.

Balakumar S., Rajan S., Thiyagarajan T. and Jeeva S. 2011. Antifungal activity of Ocimum sanctum Linn. (Lamiaceae) on clinically isolated dermatophytic fungi. Asian Pac. J. Trop. Med. 4(8): 654-657.

Cowan M.M. 1999. Plant products as antimicrobial agents. Clin. Microbiol. Rev. 12:564-582.

Curvetto N. R., Figlas D., Devalis R. and Delmastro S. 2002. Growth and productivity of deferent Pleurotus ostreatus strains on sunflower seed hulls supplemented with $\mathrm{N}_{-} \mathrm{NH}_{4}{ }^{+}$ and/or Mn(II). Bioresour. Techonol.,84: 171-176.

Da Silva M., Naozuka J., Oliviera V., Vancetti D., Bazzolli H., and Kasuya C. 2012. Enrichment of Pleurotus ostreatus mushrooms with Selenium in coffee husks. Food Chem., 131: 558563.

Dias E. S., Koshikumo E. M. S., Schwan R. F., and Silva R. 2003. Cultivation of the mushroom Pleurotus saja-cajuin different agricultural residues. Ciênc. Agrotec., 27(6): 1363-1369.

Edeoga H.O. and Enata D.O. 2001. Alkaloids, tannins and saponins content of some medicinal plants. J. Med. Arom. Plant Sci., 23:344-349

Estrada E. R., Lee H., Beelman R. B., Gasco M. M., and Royse D. J. 2009. Enhancement of the antioxidants ergothioneine and selenium in Pleurotus eryngii var. eryngii basidiomata through cultural practices. World J. Microb. Biot., 25: 1597-1607

Filipic M., Umek A. and Mlinaric D. 2002. Screening of Basidiomycete mushroom extracts for antigenotoxic and bioantimutagenic activity. Pharmazie, 57: 416-20.

Finley J. W., Sigrid-Keck A., Robbins R. J., and Hintze K. J. 2005. Selenium enrichment of broccoli: Interactions between selenium and secondary plant compounds. J. Nutri., 135: $1236-1238$.

Hartikainen H. 2005. Biogeochemistry of selenium and its impact on food chain quality and human health. J. Trace Elem. Med. Biol., 18: 309-318.

Iwalokun B. A., Usen U. A., Otunba A. A. and Olukoya D. K. 2007. Comparative phytochemical evaluation, antimicrobial and antioxidant properties of Pleurotus ostreatus. Afr. J. Biotechnol., 6 (15): 1732-1739

Karaman M., Jovin E., Malabasa R., Matavuly M. and Popovic M. 2010. Medicinal and edible lignocolous fungi as natural sources of antioxidative and antibacterial agents. Phytother. Res., 24(10): 1473-1481 
Karou D.S., Tchadjobo T., Denise P.I. and Jacques S. 2011. Sub-Saharan Rubiaceae: A review of their traditional uses, phytochemistry and biological activities. Pak. J. Biol. Sci., 14: 149-169

Khatun S., Islam M., Cakilcioglu U., Gular P., and Chatterjee N. (2015): Nutritional qualities and antioxidant activity of three edible oyster mushrooms (Pleurotus spp). NJASWAGEN J LIFE SC,72-73: 1-5.

Lindequist U., Niedermeyer T.H.J. and Julich W-D. 2005. The pharmacological potential of mushrooms. Review. Evid. Based Complementary Altern. Med., 2(3): 285-99.

Ling L.L., Schneider T., Peoples A.J., Spoering A.L., Engels I., Conlon B.P., Mueller A., Schaberie T.F., Hughes D.E., Eostein S., Jones M., Lazarides L., Steadman V.A., Cohen D.R., Felix C.R., Fetterman K.A., Millett W.P., Nitti A.G., Zullo A.M., Chen C. and Lewis K. 2015. A new antibiotic kills pathogens without detectable resistance. Nature, 517 (7535): 455-459

Maseko T., Callahan D. L., Dunshea F. R., Doronila A., Kolev S. D., and Ng K. 2013. Chemical characterisation and speciation of organic selenium in cultivated selenium-enriched Agaricus bisporus. Food Chem., 141:3681-3687

Milovanović I., Brčeski I., Stajić M., Knežević A. and Vukojević J. 2013. Potential enrichment of medicinal mushrooms with selenium to obtain new dietary supplements. Int. J. Med. Mushrooms, 15(5): 449-455

Munoz A. H. S., Kubachka K., Wrobel K., Corona J. F. G., Yathavakilla S. K. V., Caruso J.A. 2006. Se-enriched mycelia of Pleurotus ostreatus: distribution of selenium in cell walls and cell membranes/cytosol. J. Agric. Food Chem., 54(9): 3440-3444

Ogidi C.O., Nunes M.O., Da Silva M., Oyetayo V.O., Akinyele B.J. and Kasuya M.C. 2017. Growth rate and selenium bioaccumulation in Pleurotus species cultivated on signal grass, Urochloa decumbens (Stapf) R.D. Webster. Curr. Res. Nutri. Food Sci., 5(2): 137-143

Olsen N. 2018. Selenium deficiency. Avalaible from https: /www.healthline.com/health/selenium-deficiency/

Omojate G.C., Enwa F.O., Jewo A.O. and Eze C.O. 2014. Mechanisms of antimicrobial actions of phytochemicals against enteric pathogens. J. Pharm. Chem. Biol. Sci., 2(2): 77-85

Oyetayo V.O., Dong C.-H. and Yao Y.-J. 2009. Antioxidant and antimicrobial properties of aqueous extract from Dictyophora indusiata. Open Mycol. J., 3:20-26

Papp L. V., Holmgren A. and Khanna K. K. 2010. Selenium and selenoproteins in health and disease. Antioxid. Redox Signal., 12:793-795

Parihar S., Virani K.D., Pithawala E.A., Shukla M.D., Lahiri S.K., Jain N.K. and Modi H.A. 2015. Phytochemical screening, total phenolic content, antimicrobial and antioxidant activity of wild edible mushroom, Pleurotus spp. Int. Res. J. Pharm., 6(1): 65-69

Pauliuc I. and Botău D. 2017. Antibacterial activity of Pleurotus ostreatus gemmotherapic extract. J. Horti. For. Biotechnol.. 17(1), 242- 245

Rathore H., Sharma A., Prasad S. and Sharma S. 2018. Selenium bioaccumulation and associated nutraceutical properties in Calocybe indica mushroom cultivated on Se-enriched wheat straw. J. Biosci. Bioeng., 126(4): 482-487.

Ravaglia G., Forti P., Maioli F., Bastagali L., Facchini A., Mariani E., Savarino L., Sassi S., Cucinotta D. and Lenaz G. 2000. Effect of micronutrient status on natural killer cell immune function in healthy free-living subjects aged $\geq 90$ Y. Am. J. Clin. Nutr., 71(2): $590-598$

Selima K. 2012. Research on mushroom as a potential source of nutraceuticals: A review on Indian perspective. Am. J. Exp. Agric., 2: 47-73.

Shashirekha M. N., Rajarathnam S. and Bano Z. 2005. Effects of supplementing rice straw growth substrate with cotton seeds on the analytical characteristics of the mushroom Pleurotus florida (Block \& Tsao). Food Chem., 92: 255-259. 
Xie L.P., Chen O.X., Huang H., Wang H.Z., and Zhang R.Q. 2003. Inhibitory effects of some flavonoids on the activity of mushroom tyrosinase. Biochemistry (Mosc), 68: 487-491.

Zhao L., Zhao G., Zhao Z., Chen P., Tong J. and Hu X. 2004. Selenium distribution in a Seenriched mushroom species of the genus Ganoderma. J. Agric.Food Chem., 52, 39543959. 